\title{
Male secondary sexual characters in Aphnaeinae wings (Lepidoptera: Lycaenidae)
}

\author{
Zs. BÁlint ${ }^{1}$, A. HEATH ${ }^{2}$, G. KATONA ${ }^{3}$, K. KertéSZ ${ }^{4}$ \& Sz. SÁFiÁN ${ }^{5}$ \\ ${ }^{1}$ Zsolt Bálint, Department of Zoology, Hungarian Natural History Museum, Budapest, Baross u. 13, \\ H-1088, Hungary.E-mail: balint.zsolt@nhmus.hu \\ ${ }^{2}$ Alan Heath, Iziko South African Museum, Cape Town, South Africa.E-mail: alan.heath3@gmail.com \\ ${ }^{3}$ Katona Gergely, Department of Zoology, Hungarian Natural History Museum, Budapest, Baross $u .13$, \\ -1088, Hungary.E-mail: katona.gergely@nhmus.hu \\ ${ }^{4}$ Krisztián Kertész, Nanostructures Department, Institute of Technical Physics and Materials Sciences, \\ Centre for Energy Research, Hungarian Academy of Sciences, Budapest, POB 49, H-1515 Hungary. \\ E-mail:kertesz@mfa.kfki.hu \\ ${ }^{5}$ Szabolcs Sáfián, Faculty of Forestry, University of West Hungary, Bajcsy-Zsilinszky u. 4, Sopron \\ H-9400, Hungary.E-mail: safian@bcghana.org
}

\begin{abstract}
Male secondary sexual characters have been discovered on the hindwing verso of genera Aphnaeus Hübner, [1819], Cigaritis Donzel, 1847, Lipaphnaeus Aurivillius, 1916 and Pseudaletis Druce, 1888 representing the Palaeotropical subfamily Aphnaeinae (Lycaenidae: Lepidoptera). Relevant wing parts are illustrated, described, and some observations on the organs are briefly annotated. With an appendix and 14 figures.
\end{abstract}

Keywords. Androconia, hair tuft, classification, Palaeotropics, scaling.

\section{INTRODUCTION}

$\mathrm{O}$ ne of the most characteristic features of Lepidoptera is the scaled membranous wing surface of the imagines. The scales covering the membrane have various functions often determined sexually, hence they show specialized structures. In the family Lycaenidae male secondary sexual characters in the wings are widely distributed and highly variable, hence they drew the attention of classical workers focused on the diversity, classification, and systematics of the family. In a world-wide review, John Nevill Eliot $(†$ 2003) mapped and discussed Lycaenidae male secondary sexual characters in great detail for his classification (see Eliot 1973).

The subfamily Aphnaeinae was recently the subject of important studies (Heath 1997, Boyle et al. 2015). These were inspired by Eliot who pointed out the peculiarity of this lycaenid assemblage and recorded morphological traits for his classification (Eliot 1973: 470 in footnote no. 11; and Eliot 1990). However, Eliot did not indicate any male secondary sexual characters in this subfamily, nor did any of the previous or subsequent workers (eg. Stempffer 1954, Heath 1997, Libert 2013).

Whilst curating aphnaeine material in the Hungarian Natural History Museum one of us became aware of special scaling present on the hindwing underside of certain males (Figs. 1-2). This character was recorded and described in detail in the case of genera Pseudaletis and Aphaneus without using the expression that they may have a sexual role (cf. Libert 2007: 11; Libert 2013: 21213). After studying additional material and conduct some microscopic studies it became obvious that hitherto unrecognized secondary male sexual characters in Aphnaeinae were discovered. The aim of this paper is to report on this discovery, to describe the characters, to present a brief overview of their generic distribution, and to comment our results in the light of recent knowledge regarding the subfamily. 


\section{MATERIAL AND METHODS}

All material examined are listed in Appendix. Genus-level classification of the Aphnaeinae follows Boyle et al. (2015).

Specimens were first inspected using a hand magnifier, then relevant wing areas were digitised using a binocular stereo microscope Olympus SZX12 supplemented by camera DP70 in the Hungarian Natural History Museum (HNHM). In the Institute of Technical Physics and Materials Science (Centre for Energy Research, Hungarian Academy of Sciences) (CER-HAS) images of high magnification were taken using an optical miscroscope Zeiss Axio Imager A1.

Terminology of veins, wing regions and scales follows Ehrlich \& Ehrlich (1961), Eliot (1973) and Scott (1990).

\section{RESULTS}

Examining the hind wing ventral surfaces of the aphnaeine genera in the representatives of Aphnaeus Hübner, [1819] (type species: Papilio orcas Drury, [1782]), Lipaphnaeus Aurivillius, 1916 (type species: Aphnaeus spindasoides Aurivillius, 1916), Pseudaletis Druce, 1888 (type species: Pseudaletis agrippina H. H. Druce, 1888) and several taxa in Cigaritis Donzel, 1847) (type species: Cigaritis zohra Donzel, 1847) we have found male secondary sexual characters (Figs. 1$6)$, that we briefly describe below.

Aphnaeus, Cigaritis and Lipahnaeus (Figs. 1, $4-6,7-8,10,12,14)$ : In the intervenial area of the cell formed by veins Cubitus 1-2 there is a "line" comprised of long plume scales erecting caudad from the wing membrane. These hair scales form a tuft that can be seen even under low magnification. The tuft forms a somewhat differently coloured (darker compared to the background) delicate line running from the submedian area to the postmedian region. The line never reaches the base nor the margin of the wing. The region between the veins is often creased, especially in Aphnaeus.

The tuft is more easily seen in living individuals, because in set museum specimens the hair scales are often adpressed to the level of the cover scales, hence they are difficult to detect. This may explain why this scaling has hitherto remained unnoticed. In living specimens the space involved is often creased, and this results in the tuft being exposed and clearly visible when the individual perches (Fig. 14).

Regarding Aphnaeus our material was limited (see Appendix), but consulting recent literature (d'Abrera 2009, Libert 2013) it seems that the presence of the tuft is not limited to the species of $A$. orcas and $A$. argyrocyclus as has been indicated but it is more widespread. This has been confirmed by our studies.

The representatives of Cigaritis are well documented in the folio books of d'Abrera (1986, 1993, 2009) also in (Kielland 1991, Larsen 1994, Weidenhoffer \& Bozano 2007). We found that whilst Afrotropical and Oriental species probably all possess the tuft, species inhabiting the Palaearctic region do not. Although we could examine only two species of the less diverse genus Lipaphnaeus ( $\mathrm{n}=4$, sensu Heath 1997), we presume that all the species possess the male secondary character discussed as the figures in d'Abrera (2009) suggest this is the case.

Pseudaletis (Figs 3, 9-10, 13): The wing membrane in the cell formed by the veins Cubitus $1-2$ from the postbasal area to the outer margin is covered by long plume scales erecting caudad but they do not form any tuft. Along the veins Cubitus 2 there are androconia (presumably scent disseminating) mixed with ordinary cover- and ground-scales. The membrane of the intervenial area is creased.

According to the current literature (Libert 2007, d'Abrera 2009) There are 24 species in Pseudaletis divided into three species-groups. We recorded alar male sexual character only in the taxa representing the species group $P$. leonis. 

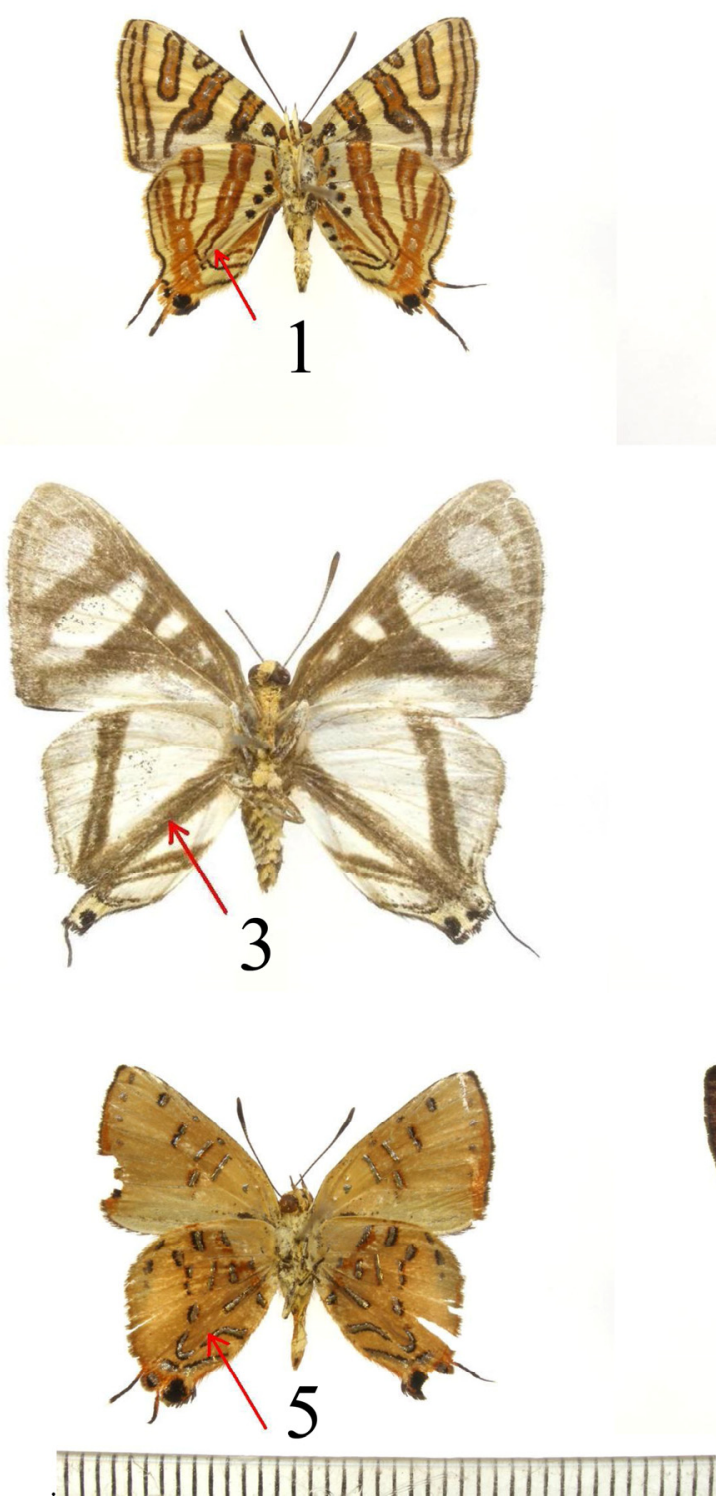
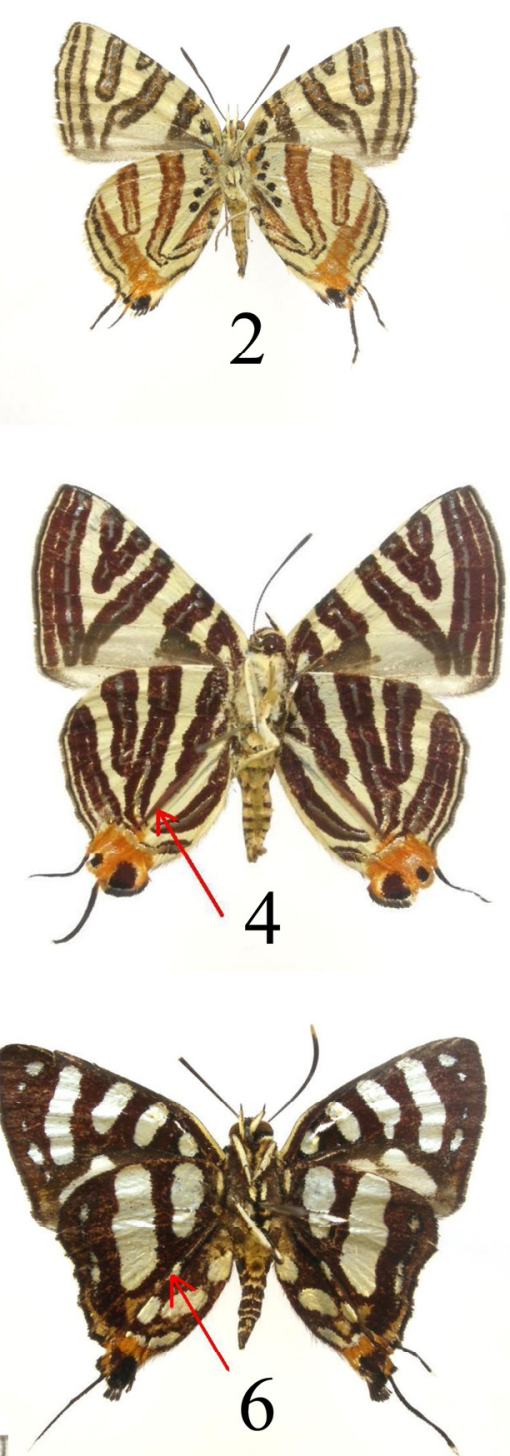

Figures 1-6. Imagines of Aphnaeinae, in ventral view. The arrows indicate the position of the alar male sexual character. 1 = Cigaritis larseni (Bouyer, 2012), male (Ghana), 2 = ditto, female (no brush organ); $3=$ Pseudaletis leonis (Staudinger, [1888], male; 4 = Cigaritis syama (Horsfield, [1829]), male (Thailand); 5 = Lipaphnaeus leonina (Bethune-Baker, 1904), male (Iberia); 6 = Aphnaeus orcas (Drury, 1782), male (Ghana) (all at the same magnification, $1 \mathrm{~mm}$ scale as indicated) (photos: G. Katona, HNHM).

\section{DISCUSSION}

It is curious that despite much of scientific attention, aphnaeine male secondary sexual characters remained overlooked for a long time, and it is surprising that classical workers paying great attention to special characters, missed them. Although it is not surprising that in lithographic figures the delicate and hardly visible alar brush organ is never conspicuous (for example: Aurivillius 1925, Murray 1935), in more recent publications the figures produced using more advanced photography, we found the pattern formed by the specialized hair scales is often more clearly visible, or at least detectable with greater certainty (see d'Abrera 1986, Kielland 1991, Larsen 1991, 


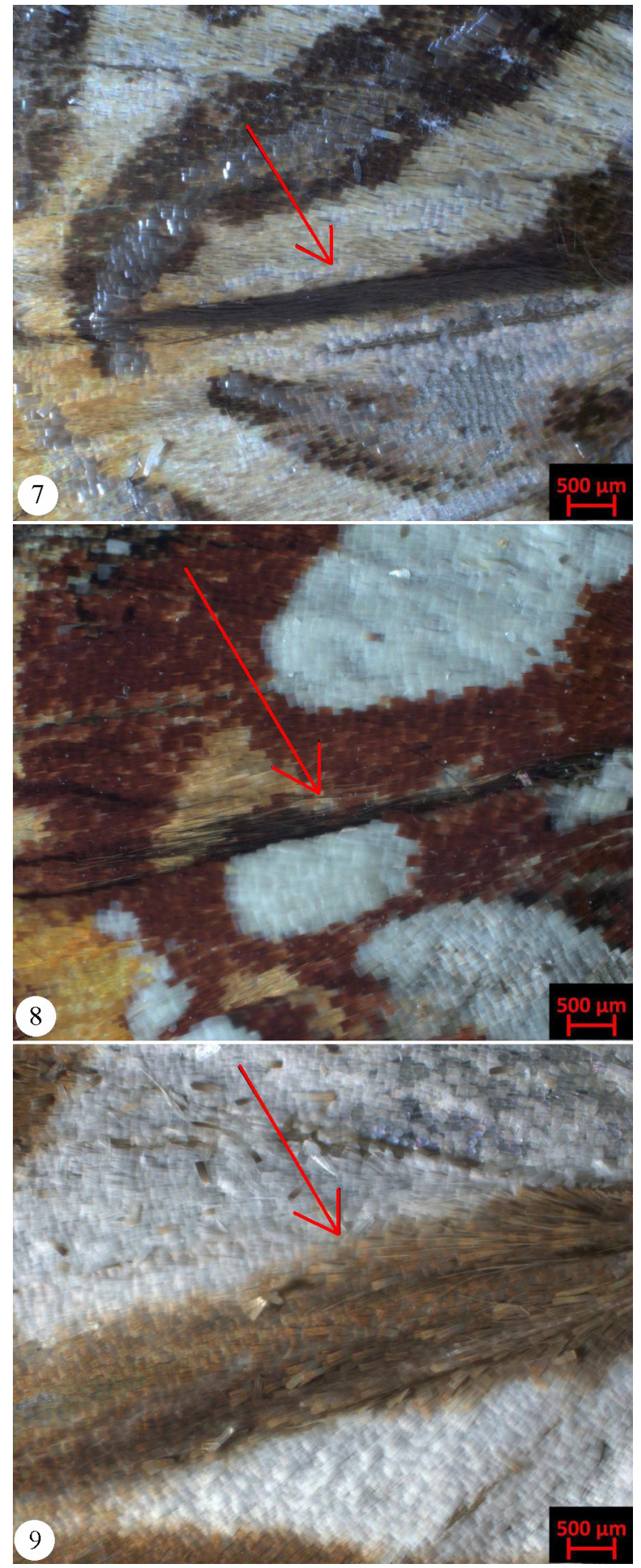

Figures 7-9. Male aphnaeine hindwing ventral surface sexual characters at high magnification, indicated by red arrows. $7=$ Aphnaeus orcas (Drury, 1782); $8=$ Cigaritis lohita (Horsfield, [1829]), 9 = Pseudaletis leonis Staudinger, [1888], (scales as indicated) (Photos: K. Kertész, CER-HAS).
1993, Weidenhoffer \& Bozano 2016, Libert 2007, d'Abrera 2009; Libert, 2013 and Weidenhoffer et al., 2016).

Because of the complex optical appearance of the Aphnaeus ventral wing surface, and that the space is often creased, it is sometimes difficult to detect the tuft in illustrations or even in actual specimens. Therefore careful examination of museum material is obligatory for mapping the distribution of the male secondary character in the genus.

An interpretation of our findings in Cigaritis is problematic in regard to genus-level classification. According to Boyle et al. (2015) the genus Cigaritis includes all the taxa, which were formerly classified as Spindasis Wallengren, 1857 (type species: Spindasis masilikazi Wallengren, 1857) and Apharitis Riley, 1925 (type species: Polyomamtus epargyros Eversmann, 1854). Taxa considered representing the genus Spindasis by some workers (e.g. Larsen 2005, d'Abrera 2009) all have the hair tuft, whilst Cigaritis sensu str. and Apharitis do not. This suggests that lumping Apharitis with Cigaritis may reflect the reality, but Palaeotropical Cigaritis might deserve the generic name Spindasis (having almost 60 species according to Bridges 1994) - if we take the hair tuft as an important character for classification. However, the uniform type of male genitalia as well as their facies mitigate against such splitting, and also there is a growing evidence that male secondary characters are not stable (see for example Robbins et al. 2012, 2015 and Martins et al. 2016). Nevertheless this needs a thorough analysis of all the taxa, as male secondary sexual characters are often difficult to interpret regarding phylogenetics.

The four aphnaeine genera (Aphnaeus, Cigaritis, Lipaphnaeus and Pseudaletis) possessing male secondary sexual character are paraphyletic in the hypothetical phylogenetic tree provided by the most recent paper on the subfamily (Boyle et al. 2015). We note that these genera represent both of the main aphnaeine lineages being sisters to each other, and in one of the lineages there is a basal genus with androconia (Pseudaletis). 

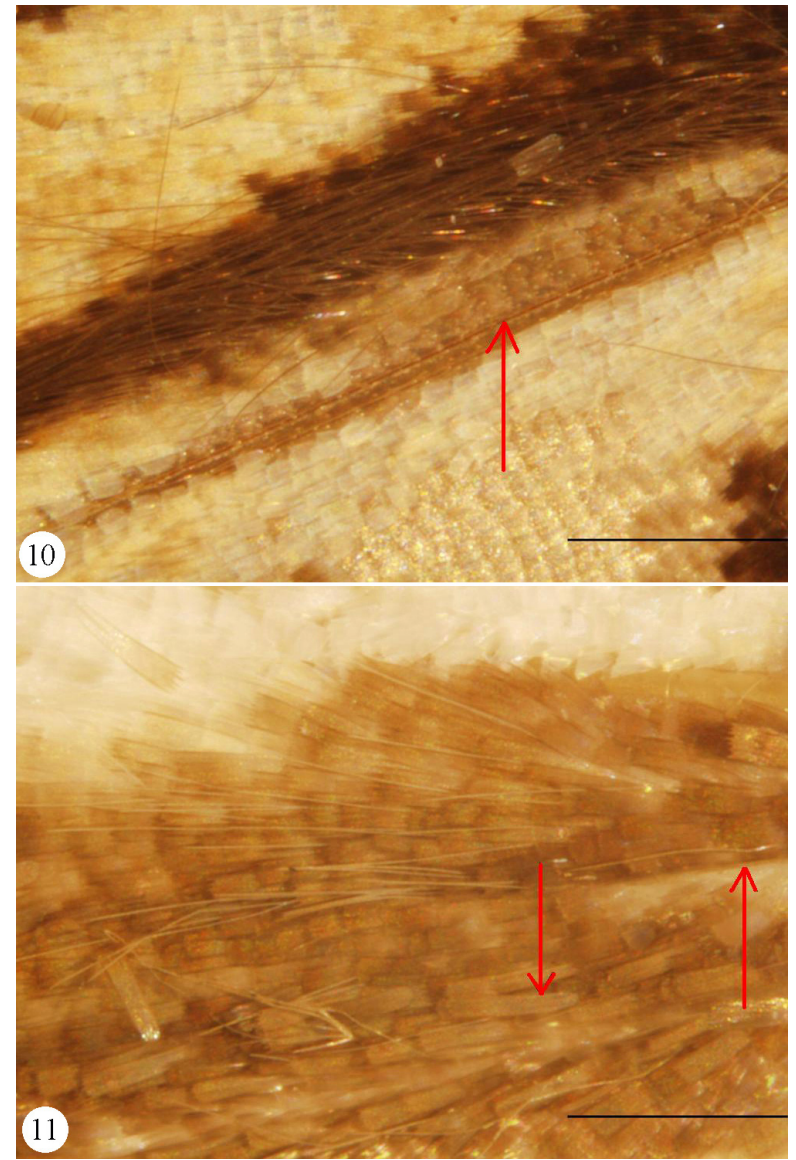

Figures 10-11. Aphnaeine scaling at high magnification. 10 $=$ Cigaritis formosanus (Moore, 1877), the vein Cubitus 2 is well visible in the lower half of the image (indicated by arrow pointing up) and there are no androconia around or under the long plume scales. $11=$ Pseudaletis leonis Staudinger, [1888]), a small part of the naked vein Cubitus 2 is visible on the right side of the image (arrow pointing up), and androconial scales (indicated by arrow pointing down) mixed with hair scales, ordinary cover- and ground scales are de-

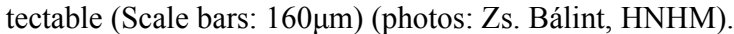

Although the sister group of Aphnaeinae has not yet been identified, it is suggested that it is the sister of the lineage containing all the other subfamilies recognized in Lycaenidae (Boyle et al. 2015: 7). If so, Pseudaletis represents one of the most basal lineages of the family. What this might imply is that the presence of a ventral hindwing male sexual organ was once a general character, but it was subsequently lost and later regained several times independently.
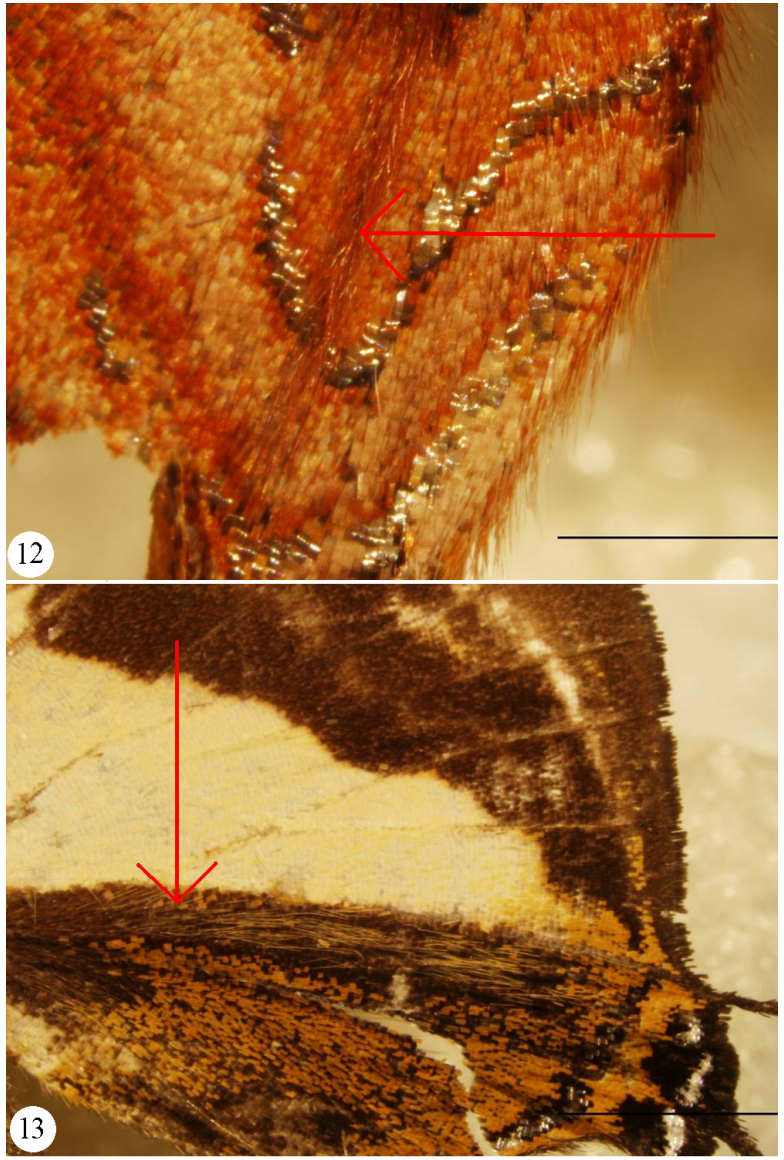

Figures 12-13. Aphnaeine male hindwing ventra with special scaling: 12 = Lipaphnaeus aderna (Plötz, 1880), red arrow indicates the long plume scales erecting caudad from the wing membrane in the cell formed by the veins Cubitus $1-2$ and forming a tuft (scale bar: $2 \mathrm{~mm}$ ); 13 = Pseudaletis antimachus (Staudinger, 1888), red arrow indicates the long plume scales dispersed on the wing membrane between the cell area formed by the veins Cubitus 1-2 (scale bar: $4 \mathrm{~mm}$ ) (photos: Zs. Bálint, HNHM).

It is interesting, that Eumaeini, which can be considered as a "primitive" group in Lycaenidae (see Eliot 1973: 454), offers analogues for the aphnaeine male secondary sexual characters (see Faynel \& Bálint 2012). For example in the genus Theritas Hübner, [1818] and its relatives there is a ventral hindwing cubital pouch (see Bálint 2006 and Robbins et al. 2012). In the genus Brangas Hübner, [1819], there is a pouch with hairpencils between vannal veins 2 and 3 (Bálint \& Faynel 2009). And in this context it is also interesting 
that the character of a female abdominal tuft is also shared by aphnaeine (Pseudaletis, Chloroselas Butler, 1886 and Trimenia Tite \& Dickson, 1973) and eumaeine lycaenids (for Neolycaena de Nicéville, 1890 and Satyrium Scudder, 1876 see in Weidenhoffer et al., 2016).

Female abdominal tufts are also present in Riodinidae (eg. Sarota Westwood, [1851], see Hall 1998) and also in some hesperiid genera (eg. Tagiades Hübner, 1819, Alan Heath, unpublished), and even some moths in the Geometridae and Tortricidae (see Pellmyr 1980). Hence, the abdominal tufts also pose interesting questions regarding higher level classification in Lycaenidae, as well as in other Lepidoptera families (see for Hesperiidae: Warren et al., 2009).

What is the function of these aphnaeine organs in vivo we reported on? We do not know yet. For Pseudaletis probably it is a scent-disseminating organ, as we were able to detect androconia at the base of the hair scales, which supposedly contained aphrodites. The physiological role of a hair tuft in Aphnaeus, Cigaritis and Lipaphnaeus is a mystery to us as we were unable to find any androconia under the hair-scales, or on the hindwing dorsal surface of the female there is nothing unusual, merely the normal scaling. Is it an organ that has lost its function? These questions need to be answered in future studies.

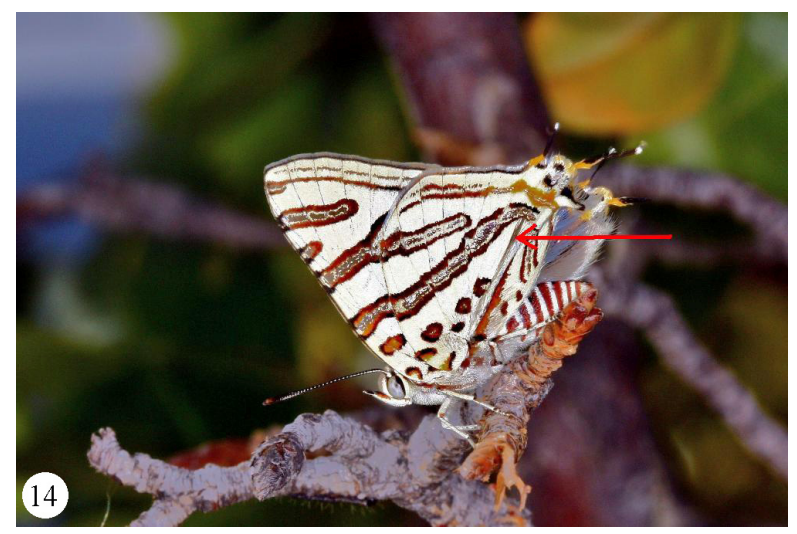

Figure 14. Perching male of Cigaritis natalensis (Westwood, 1852); the red arrow indicates the exposed hair tuft situated between the veins Cubitus 1-2 (Photo: A. Schutte).
Acknowledgements. The authors are thankful to $\mathrm{Mr}$. Jeremy Dobson (Johannesburg, South Africa), allowing direct examination of several Southern African genera of Aphnaeinae via his kind donation of specimens to the last author. All these specimens are now deposited in the Hungarian Natural History Museum. The image used as Figure 14 was taken by Raimund Schutte (Johannesburg, South Africa), who allowed us to use it. Thanks are due to him. We are grateful also to Michel Libert (Rouen, France) and an anonymous reviewer for their valuable comments on an earlier version of the text. The paper is supported by the research grant OTKA 115724.

\section{APPENDIX}

Aphaeninae material examined. All specimens are deposited in the HNHM Lepidoptera collection excluding 16 individuals which are in loan. These specimens are indicated with RCS (= research collection of Szabolcs Sáfián, Sopron, Hungary). Genus-level classification follows Boyle et al. (2015). Genera and species are listed in alphabetical order. Species given in bold possesses male secondary sexual character on their hindwing verso. Geographical Provenance of the specimens is given verbatim according to the labels; ,?Patria?" means lack of geographical data.

AlOEIDES Hübner, [1819] - A. aranda (Wallengren, 1857): ${ }^{1}$, South Africa. A. conradsi Aurivillius,

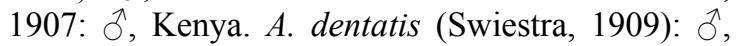
South Africa. A. pallida Tite \& Dickson, 1968: गิ, South Africa. A. pierus (Cramer, 1777): ${ }^{\lambda}$, SouthAfrica.

APHNAEUS Hübner, [1819] - A. gilloni Stempffer,

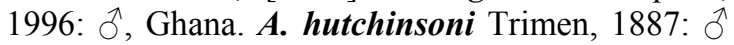
South Africa. A. jacksoni Stempffer, 1954: O, Ghana (RCS). A. nimbaensis Sáfián \& Libert, 2013: O, Liberia (RCS). A. orcas (Drury, 1782): 3 $\hat{\partial} \hat{\partial}$, + , Ghana ( $\hat{O}$,, $\mathrm{P}$ : RCS). A. zanzibarensis Grose-Smith, 1889: 2 $\delta^{\lambda}$, Kenya ( $\sigma^{\lambda}:$ RCS).

ARGYROSPODES Tite \& Dickson, 1973 - A. argyraspsis (Trimen, 1873): $\widehat{\partial}$, South Africa.

AXIOCERSES Hübner, [1819] - A. amanga (Westwood, 1881): + Congo; ${ }^{\lambda}$ Tanganyika. A. coelescens Heming \& Hemming, 1996: ô South Africa. A.

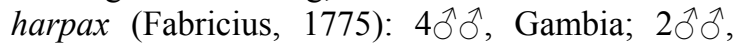

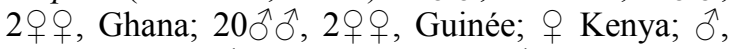

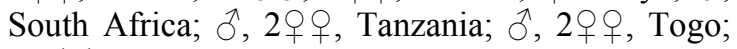

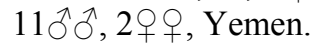


Chloroselas Butler, [1886] - C. argentomaculata (Pagenstecher, 1902): 4 ถึ่̂, ๆ Abyssinia. $C$. pseudozeritis (Trimen, 1873): $\widehat{\jmath}$, South Africa.

CHRYSORITIS Butler, [1898] - C. aethon (Trimen, 1887); 今 South Africa. C. beaufortius (Dickson, 1966); đ̂ South Africa. C. felthami (Trimen, 1904); त South Africa. C. palmus (Stoll, 1781); $\lesssim$ South Africa. C. penningtoni (Riley, 1938); त South Africa. C. pyramus (Pennington, 1953); ठ South Africa. C. zonarius (Riley, 1938); 2 ठ South Africa.

CIGARITIS Donzel, $1847-$ C. acamas (Klug, 1834): + , Afghanistan; $\hat{\jmath}$, ?Patria?; $\hat{\sigma}$, + Syria ("Cupidopsis acamas dueldueli” syntypes). C. crustaria (Holland, 1890): đै Belgian-Congo. C. elima (Moore, 1877): ふै, भ, Nepal; ô ?Patria?. C. epargyros (Eversmann, 1854): $q$ Caucasus; $q$ Kazakhstan; 4

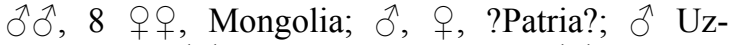
bekistan; 2 रेग, 3 우, Turkestan; 25 취, 10 우우, Turkmenistan. C. farsica (Rose \& Schurian, 1977): ก Mesopotamia; $\hat{\partial},+$, Syria. C. formosanus (Moore, [1877]): 24 ठิฎ̂, 6 qq, Taiwan. $\boldsymbol{C}$. homeyeri (Dewitz, 1886): $\hat{O}$, Zambia (RCS). C. iza (Hewitson, 1865): §̂, Zambia (RCS). C. larseni (Bouyer, 2012): ㄱ, 2 우, Gambia; + , Ghana; 2 ฮ̄ô, Togo. C. maxima (Staudinger, 1901): +

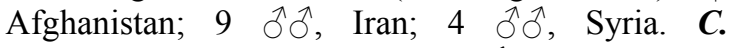
natalensis (Westwood, [1851]): $\widehat{\sigma}$, South Africa.

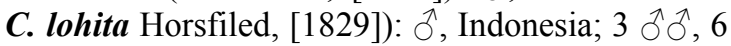
우, Thailand. C. namanga (Trimen, 1847): $\partial$, South Africa. C. phanes (Trimen, 1873): đouth Africa. C. seliga (Fruhstorfer, [1912]: $\widehat{\jmath}$ Borneo; 3

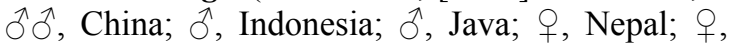

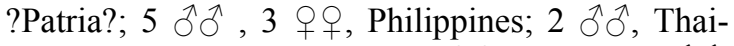
land. C. siphax Lucas, 1849: 2 우, Algeria; 2 ఏోळ, 5 우, Tunisia. C. syama (Horsfield, [1829]): స,, Nepal; 2 ऽิ, 2 우 Vietnam. C. takanonis (Matsumura, 1906): $\hat{\partial}$, + North Korea. C. trimeni (Neave, 1910): गै, Liberia (RCS). Cigaritis zohra Donzel, 1847: ふ̄, q, Algeria.

CRUDARIA Wallengren, 1875 - C. leroma (Wallengren, 1879): 0 , South Africa.

ERIKSSONIA Trimen, 1891 - E. edgei Gardiner \& Terblanche, 2010: $\widehat{O}$, South Africa.

LIPAPHNAEUS Aurivillius, 1916 - L. aderna (Plötz, 1880): $\hat{\sigma}$, + , Uganda (RCS). L. leonina (Sharpe, 1890): $\hat{\jmath}$, Ghana (RCS); $\hat{\partial}, q$, Liberia (q: RCS).

PHASIS Hübner, [1819] - P. clavum Murray, 1935: ð,, South Afrika. P. pringlei Dickson, 1977: Õ, South Africa. P. thero (Linnaeus, 1764): $\widehat{\jmath}, 2$ 우, Süd Afrika.

PSEUdAlETIS H. H. Druce, 1888 - P. antimachus (Staudinger, [1888]): $\hat{\jmath}$, Cameroon (RCS). $\boldsymbol{P}$. jolyana Libert, 2007: $\widehat{\jmath}$, Liberia (RCS). P. leonis (Staudinger, [1888]: $\hat{\jmath}$, + , Ghana (: RCS); $\hat{\jmath}, ~+$, , Liberia (RCS).

TRIMENIA Tite \& Dickson, 1973 - T. malagrida (Wallengren, 1857): $\curvearrowright$, South Africa. T. wallengrenii (Trimen, 1887): đ̂, South Africa.

TYLOPAEDIA Tite \& Dickson, 1973 - T. sardonyx (Trimen, 1868): $\hat{0}$, South Africa.

VANSOMERENIA Heath, 1997- V. rogersi Riley, 1832: O, Tanzania.

ZERITIS Boisduval, 1836 - Z. (Boisduval, 1836): 2 ふ઼ે, Guinée.

\section{REFERENCES}

Aurivillius, C. (1925): Tagfalter. In. SeITZ A. (Ed.) Die Gross-Schmetterlinge des Afrikanischen Faunengebietes. Stuttgart: Alfred Kernen Verlag, 613 pp, 80 pls.

Boyle, J.H., KALISZEWSKA, Z.A., EsPeland, M., Suderman, T., Fleming, J., Heath, A. \& Pierce N. (2015): Phylogeny of the Aphnaeinae: myrmecophilous African butterflies with carnivorous and herbivorous life histories. Systematic Entoomology 40: 169-182. doi: 10.1111/syen.12098

BRIDGES CH. (1994): Catalogue of the Family-group, Genus-group and Species-group names of the Riodinidae \& Lycaenidae (Lepidoptera) of the World. Urbana, Illinois: Author's publication, $1204 \mathrm{pp}$. doi: $10.5962 /$ bhl.title. 15814

D'ABrerA, B. (1986): Butterflies of the Oriental Region. Part III Lycaenidae \& Riodinidae. Melbourne/ London: Hill House, p. xv + 535-672.

D'ABrerA, B. (1993): Butterflies of the Holarctic Region. Part III Nymphalidae (concl.), Libytheidae, Riodinidae \& Lycaenidae. Melbourne/London: Hill House, p. i-vii + 335-524.

D'ABRERA, B. (2009): Butterflies of the Afrotropical Region. New and Revised Edition part III Lycaenidae \& Riodinidae. Melbourne/London: Hill House, p. i-xxvi + 531-884.

EHRLICH, P.R. \& Enhrlich, A.H. (1961): How to Know the Butterflies. Dubuque, Iowa: W.M.C. Brown Company Publsihers, 262 pp.

Eliot, J.N. (1973): The Higher Classification of the Lycaenidae (Lepidoptera): A Tentative Arrangement. Bulletin of the British Museum (Natural History), Entomology, 28(6): 371-505. doi: $\underline{10.5962 / \text { bhl.part. } 11171}$ 
Eliot, J. N. (1990): Notes on the genus Curetis. Tyô ta Ga 41: 201-225.

FAYNEL, CH. \& BÁLINT, Zs. (2012): An overview of alar organs in French Guiana hairstreaks (Lepidoptera: Lycaenidae: Theclinae, Eumaini). Lépidoptères de Guyane, 5: 46-54.

HALL, J.P.W. (1998): A review of the genus Sarota (Lepidoptera: Riodinidae). Tropical Lepidoptera, 9(Suppl. 1): 1-21.

HEATH, A. (1997): A Review of African Genera of the Tribe Aphnaeini (Lepidoptera: Lycaenidae). Metamorphosis, Supplement 2: 1-60.

KIElland, J. (1991): Butterflies of Tanzania. Melboure/London: Hill House, 363 pp.

LARSEN, T.B. (1991): The Butterflies of Kenya and Their Natural History. Oxford: Oxford University Press, [xvii] +490 pp. 64 pls.

LARSEN, T.B. (2005): Butterflies of West Africa. Senstrup: Apollo Books, 595 (text volume) +270 (plate volume) pp.

LIBERT, M., 2007: Révision du genre Pseudaletis Druce (Lepidoptera, Lycaenidae). Nairobi: African Butterfly Research Institute and Tervuren: Union des Entomologistes Belges, 61 pp. +14 pls.

LIBERT, M. (2013): Révision du genre Aphnaeus Hübner (Lepidoptera, Lycaenidae). Nairobi: African Butterfly Research Institute, 99 pp +13 pls.

Martins, A.R.P., FAYNEL, C. \& RobBins, R. (2016): Variation of Male Secondary Sexual Structures and the Taxonomy of Theritas lisus and Relatives (Lepidoptera, Lycaenidae, Eumaeini). Proceedings of the Entomological Society of Washington 118(4): 555-573. doi: $\underline{10.4289 / 0013-8797.118 .4 .555}$

Murray, D.P. (1935): South African Butterflies. A Monograph of the Family Lycaenidae. With descryiption and illustration of every species and figures of many of the larvae. London: Staples Press, viii + 195 pp. xii +144 figs.
Pellmyr, O. (1980): Morphology of the genitalia of Scandinavian brachypterous female Geometridae (Lepidoptera). Insect Systematics \& Evolution 11(4): 413-423. doi: 10.1163/187631280794709990

Robbins, R.K., Martins, A.R.P., Busby, R.C. \& DUARTE, M. (2012): Loss of male secondary sexual structures in allopatry in the Neotropical butterfly genus Arcas (Lycaenidae: Theclinae: Eumaeini). Insect Systematics \& Evolution 43: 35-65. doi: $\underline{10.1163 / 187631212 \times 626195}$

RoBbins, K.R., HEREDIA, M.D. \& BusBy, R.C. (2015): Male secondary sexual structures and the systematics of the Thereus oppia species group (Lepidoptera, Lycaenidae, Eumaeini). ZooKeys 520: 109-130. doi: 10.3897/zookeys.520.10134

SCOTT, J.A. (1999): Adult structure and function, pp 108-151. In. KudRNA, O. (Ed.) Butterflies of Europe, Volume 2. Introduction to Lepidopterology. Wiesbaden: Aula-Verlag, 557 pp.

STEMPFFER, H. (1954): A revision of the genus Aphnaeus Hübner (Rhopalocera: Lycaenidae). Transactions of the Entomological Sociaty, London 105: 493-516, pls I-II. doi: $10.1111 /$ j.1365-2311.1954.tb00775.x

WArren, A.D., Ogawa, J.R: \& Brower, A.V.Z. (2009): Revised classification of the family Hesperiidae (Lepidoptera: Hesperioidea) based on combined molecular and morphological data. Systematic Entomology 34: 467-523. doi: $\underline{10.1111 / \mathrm{j} .1365-3113.2008 .00463 . \mathrm{x}}$

Weidenhoffer, Z. \& BozAno, G. C. (2007): Guide to the Butterflies of the Palearctic Region. Lycaenidae part III. Subfamily Theclinae, Tribes Tomarini, Aphnaeini and Theclini (partim). Milano: Omnes Artes, 97 pp.

Weidenhoffer, Z., BozAno, G.C., Zhdanko, A. \& CHURKIn, S. (2016): Guide to the Butterflies of the Palearctic Region. Lycaenidae part II. Subfamily Theclinae, Tribe Eumaeini (partim). Milano: Omnes Artes, 106 pp. 